\title{
Optimization of Fermentative Production of Keratinase by Bacillus subtilis Strain S1 in Submerged State Fermentation Using Feather Waste
}

\author{
Sandeep Singh ${ }^{1 *}$, Harison Masih ${ }^{1}$, G. Ebenezer Jeyakumar ${ }^{2}$, \\ Rubina Lawrence $^{1}$ and P.W. Ramteke ${ }^{3}$ \\ ${ }^{1}$ Department of Microbiology and Fermentation Technology, SHUATS, Allahabad, India \\ ${ }^{2}$ Department of Clinical Laboratory Science, SHUATS, Allahabad, India \\ ${ }^{3}$ Department of Biological Sciences SHUATS, Allahabad, India \\ *Corresponding author
}

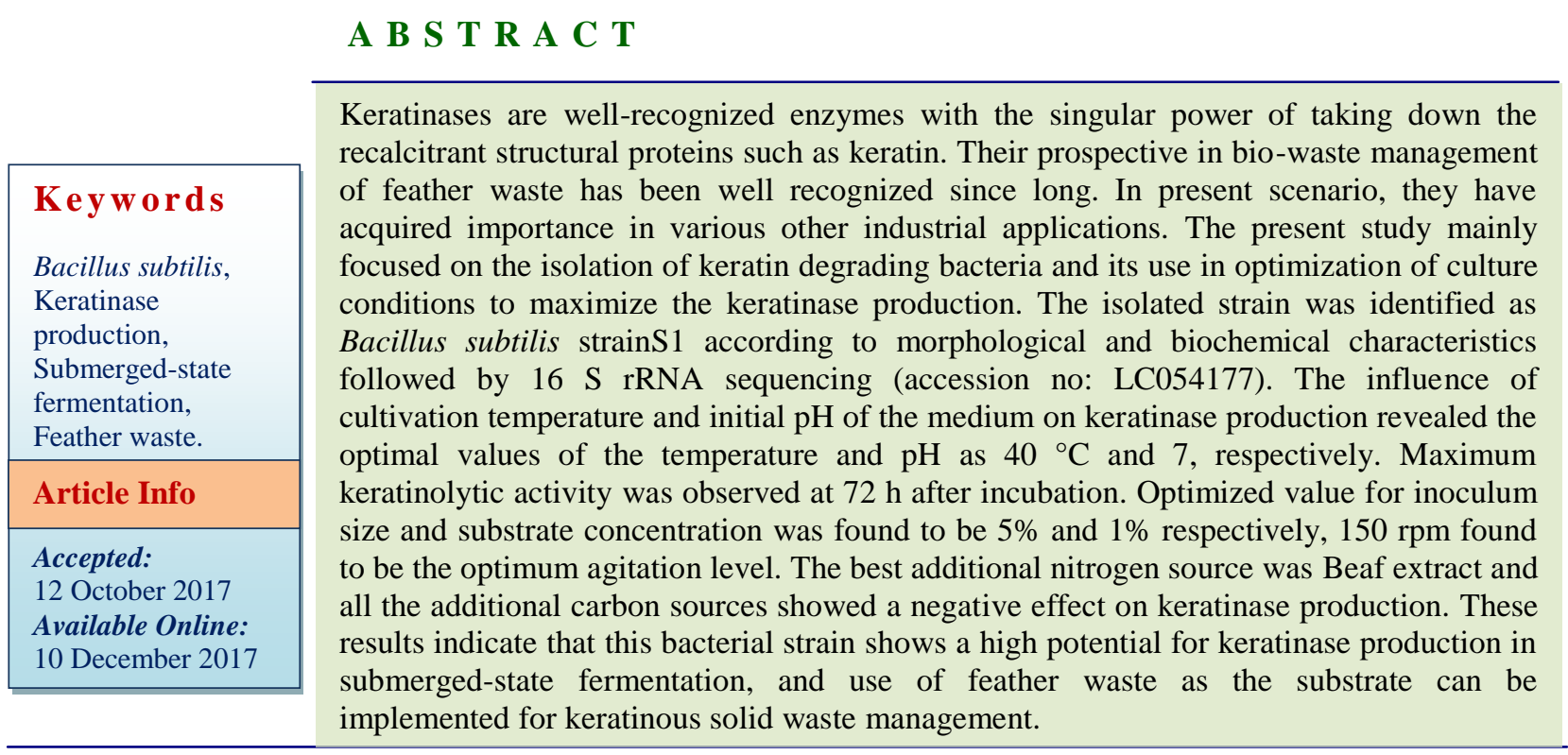

\section{Introduction}

Keratinases are well-acknowledged enzymes with the extraordinary power of taking down the unmanageable structural proteins such as keratin. Their prospective in bio-waste management of feather waste has been well established since long. In present scenario, they have acquired significance in various other industrial applications. A massive amount of fibrous insoluble protein in the form of feathers, hair, nails, horn, and other are available as byproducts of agroindustrial processing plants (Onifade et al., 1998). These keratinous wastes are very tough to degrade because of the densely packed polypeptide and several hydrogen bonds and hydrophobic interactions, in addition to several disulfide bonds. Keratin is the insoluble structural protein of feathers and wool and is known for its high stability (Bradbury 1973). In spite of their prominent resistance, keratins do not mount up in nature and can be hydrolyzed by a number of 
microorganisms. Keratinolytic enzymes are produced by fungi, actinomycetes, and bacteria and have been repeatedly isolated from soils where keratinous materials are deposited (Kaul and Sumbali, 1997; Riffel and Brandelli, 2006). Among bacteria, keratinolytic activity has been extensively acknowledged for strains from the genera Bacillus and Streptomyces (Lin et al., 1999; Kim et al., 2001; Bressolier et al., 1999). Keratinolytic enzymes from bacteria may have significant uses in biotechnological processes concerning keratin-containing wastes from poultry and leather industries through the expansion of nonpolluting processes.

Keratinase producing microorganisms have the significant industrial application in fermentation technology. Submerged fermentation of poultry waste by microorganism producing keratinase helps in the translation of non-soluble keratin (feather) into soluble protein or polypeptide (Suntornsuk and Suntornsuk, 2003). Insoluble feather keratins can be transformed after enzymatic hydrolysis to feedstuffs, fertilizers, glues, and films or used for the production of the infrequent amino acids serine, cysteine, and proline (Papadopoulos et al., 1986; Onifade et al., 1998; Gupta and Ramnani 2006). Keratinase has also promising application in dehairing process in leather industry as a replacement for sodium sulphides (Alexandre et al., 2005) and also used as a detergent to get rid of strains on cloth (Gessesse et al., 2003).

Valorization of keratin containing wastes like feathers from poultry farms and hair from leather industries may have the prospective in expansion of non-polluting processes. The mammoth augment of the poultry industry has generated bulky amounts of feathers as byproduct. The consumption of agroindustrial residues may correspond to an added significance to the industry. The whole story has encouraged the exploration for alternatives to convert unmanageable keratinous waste into precious products. In this regard the present study was conducted to optimize the keratinase production from feather waste.

\section{Materials and Methods}

\section{Isolation and screening of the feather degrading microorganisms}

The soil samples were collected from poultry waste dump sites in Allahabad, India. For each sample, $1 \mathrm{~g}$ of soil was suspended in 50 $\mathrm{mL}$ sterile distilled water. The supernatant was diluted and then laid on skimmed milk agar plate. After incubation at $37^{\circ} \mathrm{C}$ for $48 \mathrm{~h}$, clearing zones around the colony were observed to signify the protease production. A single colony with a clearing zone was picked up and inoculated on feather meal agar plate containing the following $(\mathrm{g} / \mathrm{L})$ : feather meal (10.0), $\quad \mathrm{NaCl} \quad(0.5), \quad \mathrm{K}_{2} \mathrm{HPO}_{4} \quad(0.3)$, and $\mathrm{KH}_{2} \mathrm{PO}_{4}$ (0.4). The isolated strain, which showed growth on the feather mealagar plate, was selected for further studies.

\section{Taxonomic studies and 16S rRNA sequencing}

Bacterial identification was conducted based on morphological and biochemical tests. The $16 \mathrm{~S}$ rRNA gene of the isolated strain was sequenced after genomic DNA extraction and PCR amplification. Two bacterial 16S rRNA primers, forward primer - (CCGAA TTCGTCGACAACAGAGTTTGATCCTGG CTCAG) and reverse primer - (CCCGG GATCCAAGCTTACGGCTACCTTGTTAC

GACTT), were used for gene amplification and sequencing. PCR was run for 35 cycles under the following steps: $94^{\circ} \mathrm{C}$ for $30 \mathrm{~s}$, $60^{\circ} \mathrm{C}$ for $30 \mathrm{~s}$, and $72^{\circ} \mathrm{C}$ for $1 \mathrm{~min}$. A Bio Edit version 7.2.5 DNA Analyzer (Applied 
Biosystems) was used for sequencing. The 1478-bp sequence was submitted to the Data Bank of Japan (DBJ). The nucleotide sequence of the strain was compared to any similar database sequence in the GenBank using the program BLAST version 3.2.2 via the NCBI site. The 16S rRNA sequences were aligned using clustal $\mathrm{W}$ program, and the phylogenetic tree was prepared using MEGA4 Software.

\section{Optimization of culture conditions for enzyme production}

The influence of different culture conditions on enzyme production was examined by using a medium containing feather meal as a sole source of carbon and nitrogen. The medium contained the following $(\mathrm{g} / \mathrm{L})$ : chicken feather meal (10.0), MgSO4.7H2O (0.2), K2HPO4 (1.0), $\mathrm{CaCl} 2$ (0.1), and $\mathrm{KH} 2 \mathrm{PO} 4$ (0.4). The $\mathrm{pH}$ of the medium was adjusted to 7.0. The influence of incubation period on keratinase production was examined at 24, 48, 72, 96, 120 and $144 \mathrm{~h}$. The influence of temperature on keratinase production was examined at 25 , $30,35,40,45,50,55$ and $60^{\circ} \mathrm{C}$. The keratinase production was also investigated in media with various initial pHs ranging 3.011.0. Different inoculum sizes ranging 1-3\% were also investigated. Different agitation levels ranging 50-300 rpm were also checked. Effect of substrate concentration ranging 1$3 \%$ was examined. The effect of additional carbohydrate and nitrogen sources on the keratinase production was also examined. Data were taken in triplicate. Extraction was done by taking samples from each flask and centrifuged to remove the cells and residual feathers, and keratinase activity of the supernatant was determined.

\section{Keratinase assay}

Keratinase activity was determined by taking $20 \mathrm{ml}$ of $0.1 \mathrm{~mol}^{-1}$ Tris buffer $(\mathrm{pH}$ 8) containing $0.1 \%$ feather and $40 \mu \mathrm{l}$ of enzyme solution and was incubated for 30 minutes at $55^{\circ} \mathrm{C}$. The reaction was stopped with $500 \mu$ of $0.1 \mathrm{~mol}^{-1}$ trichloroacetic acid (TCA) in 0.1 mol $^{-1}$ Tris buffer, $\mathrm{pH} 8$.

The amino acid liberated were measured as the absorbance at $590 \mathrm{~nm}$ against a reagent blank and the quantity was determined from a standard tyrosine solution (50-500 $\mathrm{g} \mathrm{m}^{-1}$ ) using a spectrophotometer(Alessandro and Adriano 2006).

\section{Results and Discussion}

\section{Isolation and screening of keratinophilic isolate}

The feather-degrading microorganism isolated from poultry waste dump site showed clear zone on skimmed milk agar plate and demonstrated pronounced growth in feather meal medium which conforms it a keratinolytic organism.

The identification of this bacterial isolate was based on cell and colony morphology, growth characteristics, several biochemical tests, and $16 \mathrm{~S}$ rRNA sequence analysis.

On the basis of morphology and different biochemical tests the isolate was identified as Bacillus subtilis.

It has been further characterized on the basis of 16s rRNA studies, and was found to be Bacillus subtilis (LC054177) having 99\% similarity with Bacillus subtilis strain PWK36 Accession Number KJ620422.

The phylogenetic tree constructed from the sequence data by using clustal $\mathrm{W}$ and MEGA version 4 software program (Fig. 1) which showed the detailed relationships between the isolated strain and other closely related species of the genus Bacillus. 
Optimization of Keratinase production by Bacillus subtilis

\section{Effect of incubation period}

The effect of incubation period for keratinase production from Bacillus subtilis was studied for the incubation period from 0 to $144 \mathrm{~h}$ as shown in (Fig. 2). It was observed that the maximum enzyme production was attained after72 $\mathrm{h}$ of incubation period. Incubation beyond the optimum time showed a rapid decline in the enzyme yield, as compared to maximum $(13.74 \mathrm{U} / \mathrm{ml})$ at $72 \mathrm{hrs}$. An increase in the enzyme production from $0 \mathrm{~h}$ towards 72 h was observed. After $72 \mathrm{~h}$ of incubation a decrease in the trend of enzyme activity towards $144 \mathrm{~h}$ was observed with minimum $(1.19 \mathrm{U} / \mathrm{ml})$ at $144 \mathrm{~h}$ of incubation period. The optimum incubation period in this study was found similar to the results of (Lin and Yin 2010) who observed maximum keratinase production after 72 h. Saibabu et al., (2013) reported maximum extracellular alkaline keratinase production after $72 \mathrm{~h}$ when $B$. megaterium was grown in the feather meal medium. Jahan et al., (2010) reported that highest enzyme production was achieved by Bacillus sp. after $72 \mathrm{~h}$ of cultivation on feather meal.

\section{Effect of incubation temperature}

The effect of incubation temperature for keratinase production from Bacillus subtilis was studied for the incubation temperature from $25^{\circ} \mathrm{C}$ to $60^{\circ} \mathrm{C}$ as shown in (Fig. 3). It was observed that the maximum enzyme production from Bacillus subtilis was attained at $40^{\circ} \mathrm{C}$ of incubation temperature. Incubation beyond the optimum temperature showed a rapid decline in the enzyme yield, as compared to maximum $(13.25 \mathrm{U} / \mathrm{ml})$ at $40^{\circ} \mathrm{C}$. An increase in the enzyme production from $25^{\circ} \mathrm{C}$ towards $40^{\circ} \mathrm{C}$ was observed. After $40^{\circ} \mathrm{C}$ of incubation temperature a decrease in the trend of enzyme activity towards $60^{\circ} \mathrm{C}$ was observed. Minimum (1.90 U/ml) enzyme activity was observed at $25^{\circ} \mathrm{C}$ and in this case no activity was detected at 55 and $60^{\circ} \mathrm{C}$ of incubation temperature. The optimum cultured temperature in this study was found similar to those in the previous reports. Bacillus sp. FK46 (Suntornsuk et al., 2003), Lysobacter sp. (Allpress et al., 2002), and Stenotrophomonas sp. D-1 (Williams et al., 1990), showed optimum temperature for growth and keratinolytic enzyme production ranging from $20{ }^{\circ} \mathrm{C}$ to $40{ }^{\circ} \mathrm{C}$. (Lin et al., 1999) indicated that the optimal range of temperature for keratinase production by feather-degrading $B$. licheniformis was between $40^{\circ} \mathrm{C}$ and $45^{\circ} \mathrm{C}$. Sahoo et al., (2012) carried out fermentation reaction at temperature range of $25-45^{\circ} \mathrm{C}$ for optimizing keratinolytic enzyme production by $B$. weihenstephaensis $P K D 5$, and found optimum temperature of $40^{\circ} \mathrm{C}$ for maximal enzyme production. Suh et al., (2001) recorded maximum temperature for keratinase production of $40^{\circ} \mathrm{C}$ with Bacillus subtilis and Bacillus pumilis.

\section{Effect of Inoculum Size}

The effect of inoculum size on the production of keratinase by Bacillus subtilis was studied for inoculum sizes of 1 to $6 \%(\mathrm{v} / \mathrm{v})$ as presented in (Fig. 4). From the results it was observed that the maximum production (14.04 $\mathrm{U} / \mathrm{ml}$ ) was obtained at $5 \%$ of inoculum size. Bacillus subtilis showed higher production of keratinase as the inoculum size was increased above $2 \%$. Minimum enzyme activity of (4.69 $\mathrm{U} / \mathrm{ml}$ ) was observed at $1 \%$ of inoculum size. Results of the present study was found similar to the previous studies as many workers have described that higher keratinase production is obtained at higher percentage of inoculum sizes, for instance (Lateef et al., 2010) observed maximum keratinase production at $5 \%$ concentration of inoculum size with $B$. cereus LAUO8 strain. 
Fig.1 Phylogenetic position of Bacillus subtilis S1 (LC054177) based on 16S rRNA sequence within the genus Bacillus. The sequences were aliened using the Clustal W program and

MEGA4 software

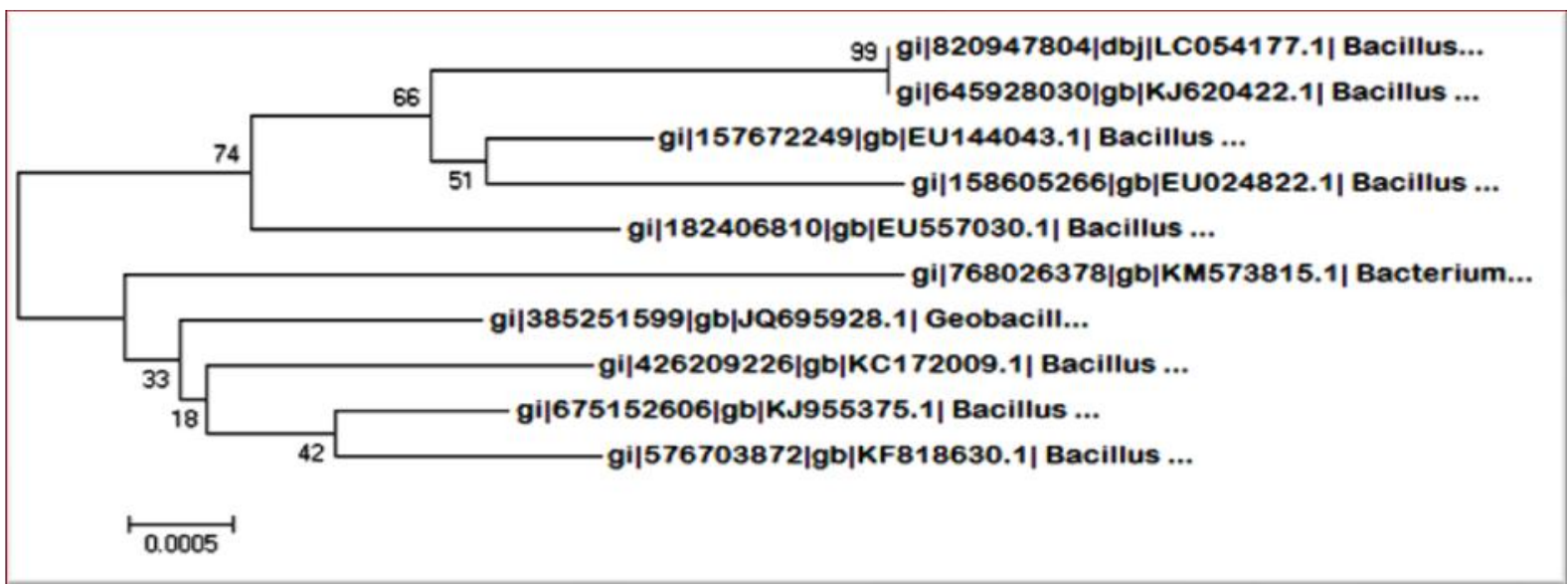

Fig.2 Effect of Incubation period on keratinase production by Bacillus subtilis S1

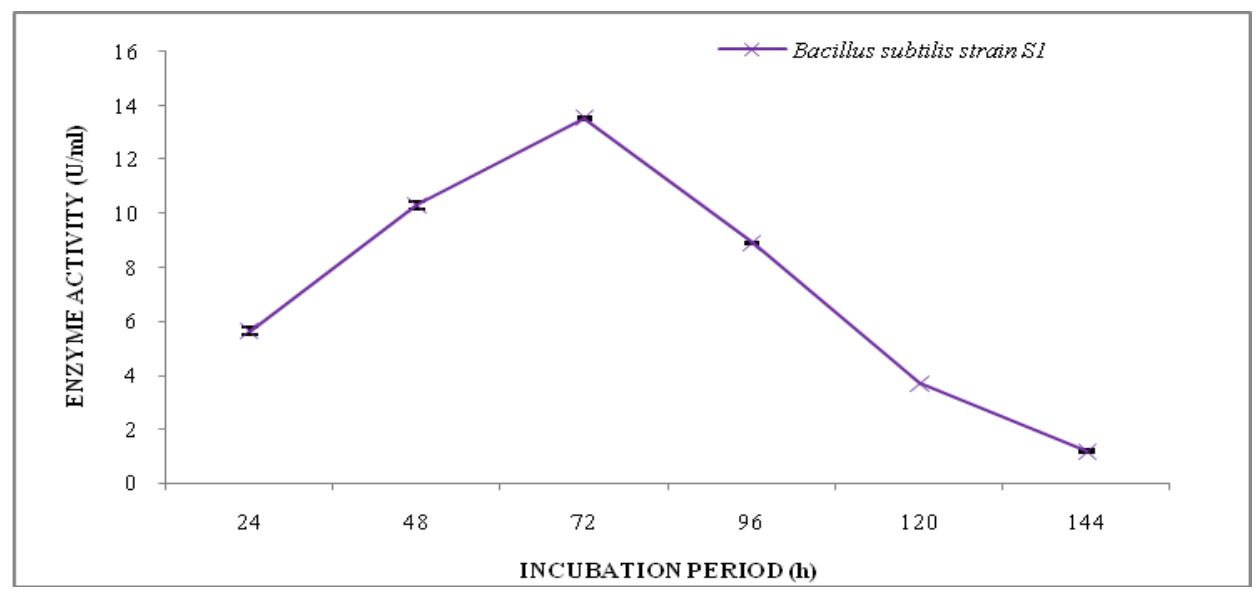

Fig.3 Effect of Incubation temperature on keratinase production by Bacillus subtilis S1

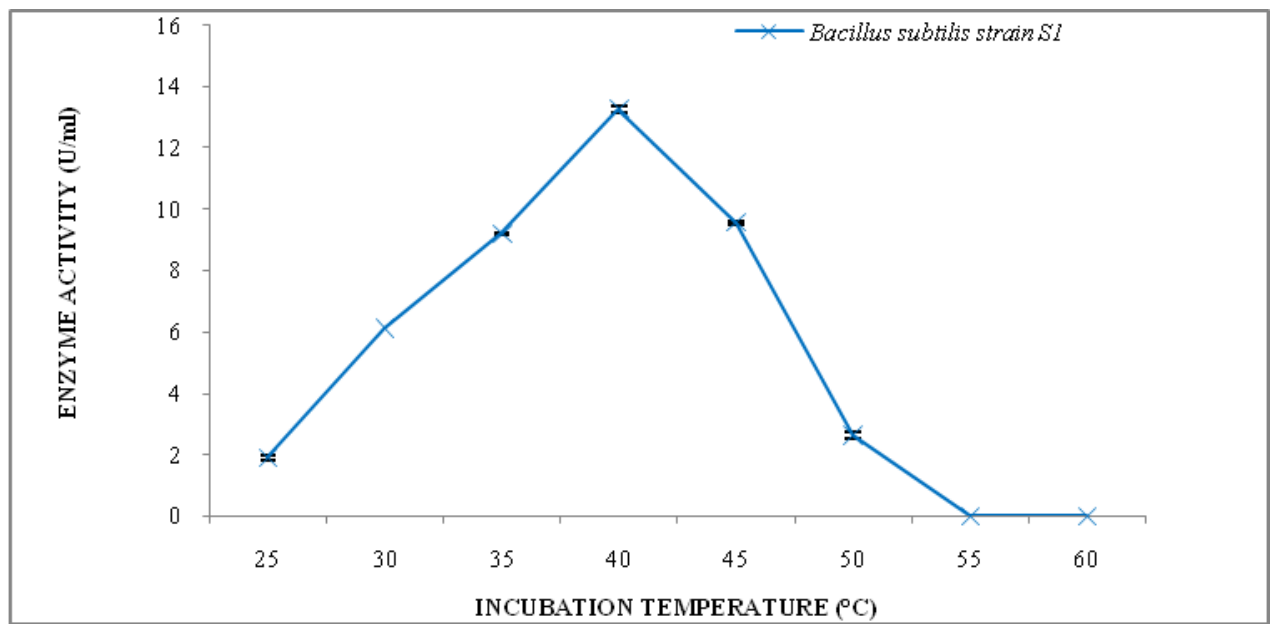


Fig.4 Effect of inoculum size on keratinase production by Bacillus subtilis S1

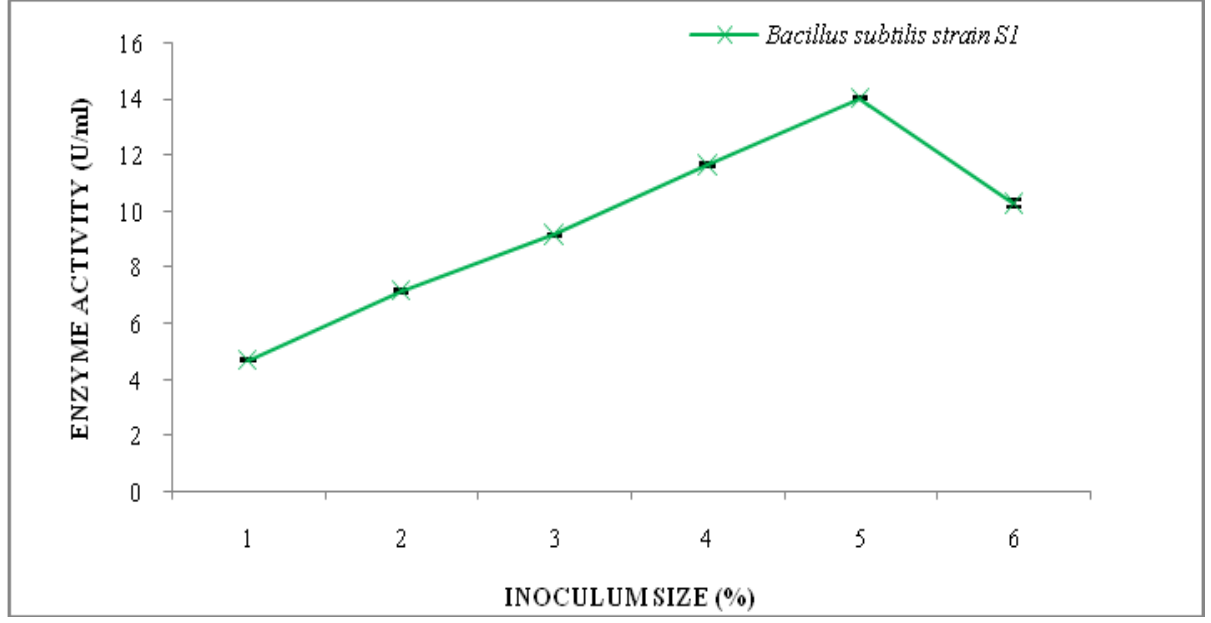

Fig.5 Effect of pH on keratinase production by Bacillus subtilis $\mathrm{S} 1$

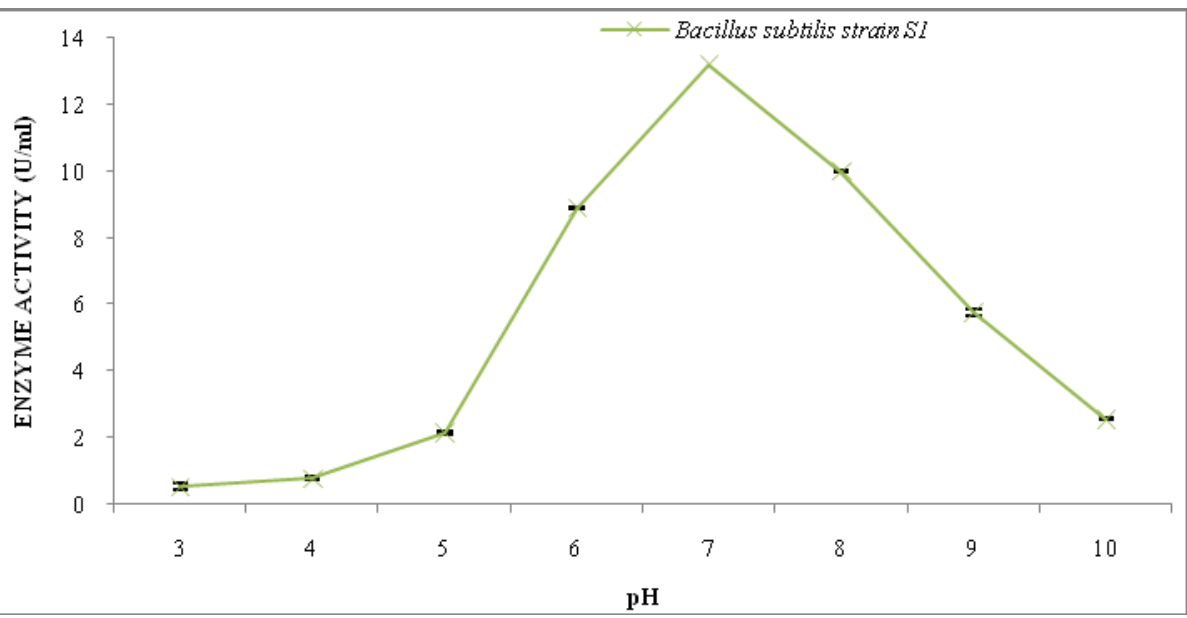

Fig.6 Effect of agitation level on keratinase production by Bacillus subtilis S1

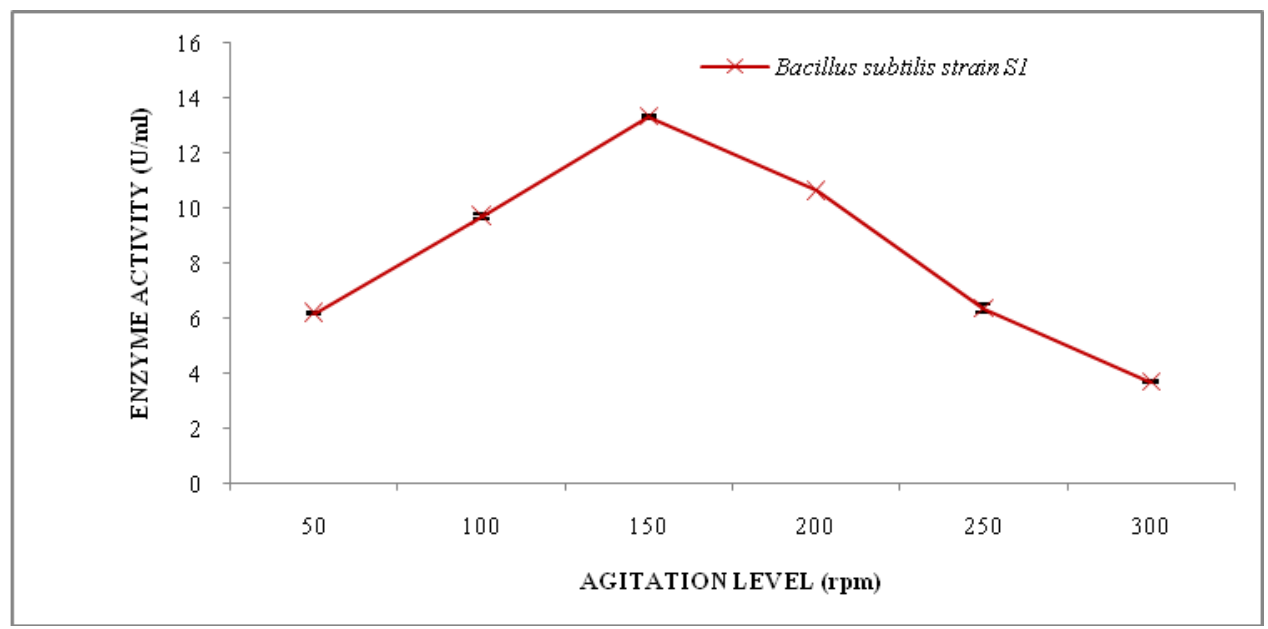


Fig.7 Effect of substrate concentration on keratinase production by Bacillus subtilis $\mathrm{S} 1$

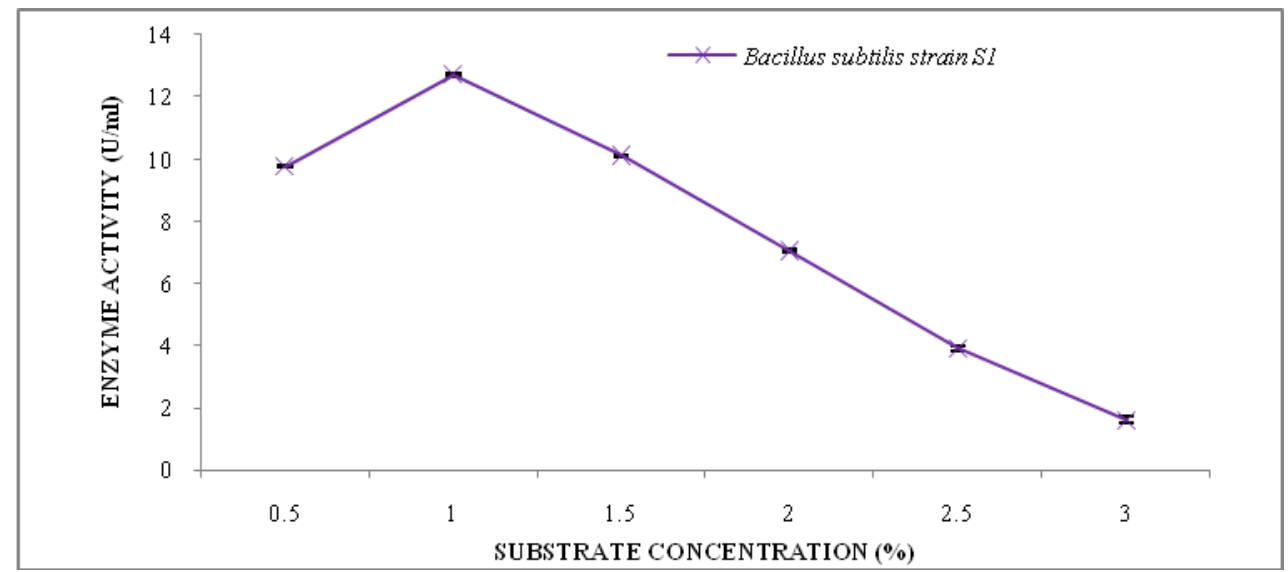

Fig.8 Effect of additional carbon source on keratinase production by Bacillus subtilis S1

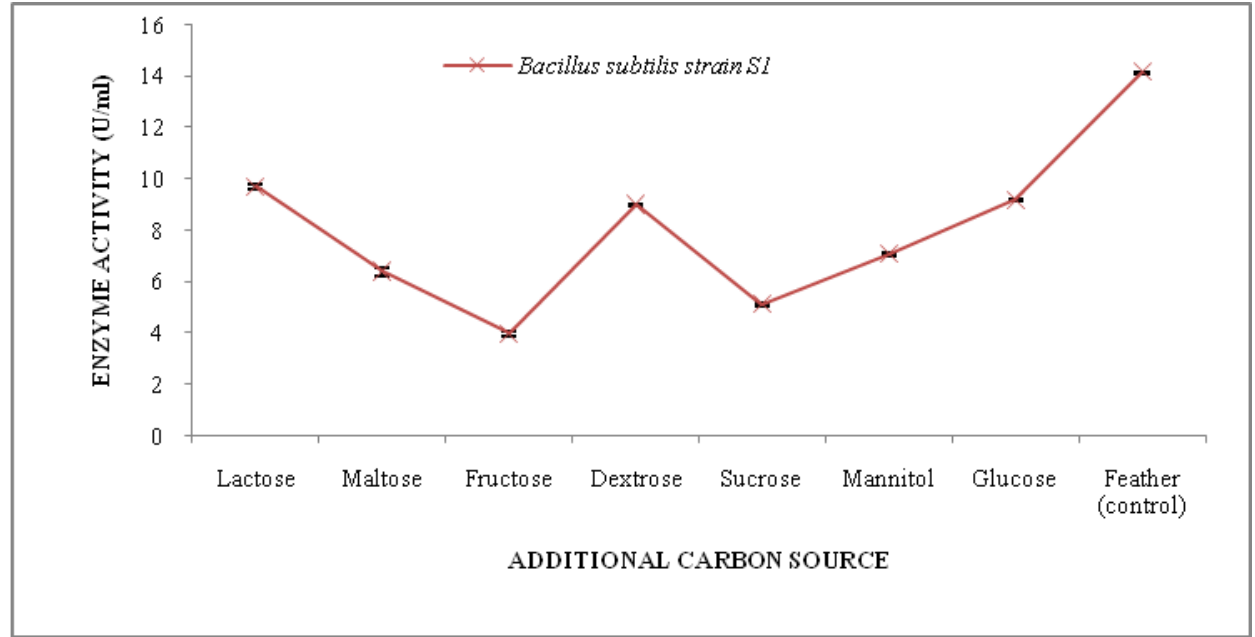

Fig.9 Effect of additional nitrogen source on keratinase production by Bacillus subtilis S1

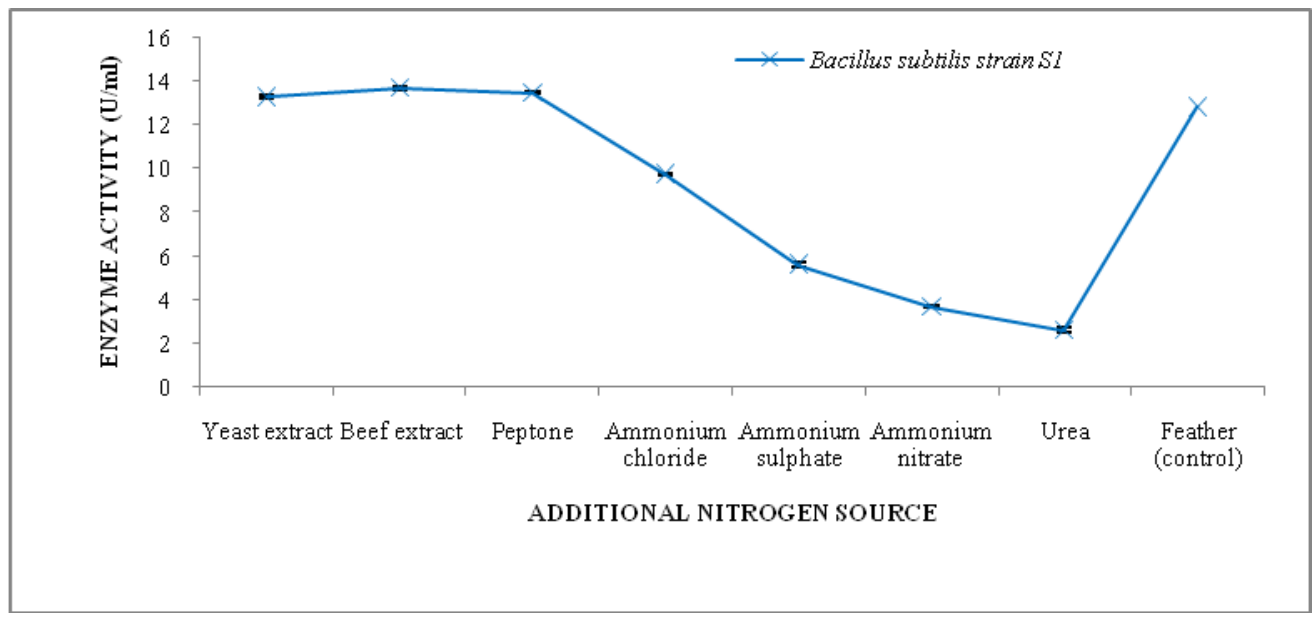


Similarly, Suntornsuk and Suntornsuk (2003) found $5 \%$ of initial inoculum as optimal for keratinase production by Bacillus sp. FK 46. Sivakumar et al., (2013) observed 4\% inoculum size to be optimum for keratinase production by B. cereus TS1.

\section{Effect of pH}

The effect of $\mathrm{pH}$ on keratinase production from Bacillus subtilis was studied for the range of $\mathrm{pH} 3$ to $\mathrm{pH} 10$ as shown in (Fig. 5). According to the results an increase in the enzyme production from $\mathrm{pH} 3$ towards $\mathrm{pH} 7$ was observed and maximum enzyme production from the bacterium was attained at $\mathrm{pH}$ 7. $\mathrm{pH}$ beyond the optimum showed a gradual decrease in the enzyme yield, as compared to maximum $(13.18 \mathrm{U} / \mathrm{ml})$ at $\mathrm{pH} 7$. After $\mathrm{pH} 7$ a decrease in the trend of enzyme activity towards $\mathrm{pH} 10$ was observed. The present results are in accordance with some of the previously reported keratinases, indicating that the keratinase produced by Bacillus species might be most active in neutral or basic conditions. Jeong et al., (2010) found 7.0 as an optimum $\mathrm{pH}$ for keratinase production by Stenotrophomonas maltophila $R$ 13. According to Suntornsuk and Suntornsuk (2003) during production of keratinase, keratin utilization occurs more rapidly and to a great extent at $\mathrm{pH}$ 7.5. Kim et al., (2001) reported the optimum $\mathrm{pH}$ for keratinase production by B. cereus at 7.0.

\section{Effect of agitation level}

In the present study effect of different agitation level i.e. $100 \mathrm{rpm}, 150 \mathrm{rpm}, 200$ rpm, $250 \mathrm{rpm}$ and $300 \mathrm{rpm}$ was studied for keratinase production by Bacillus subtilis as shown in (Fig. 6). According to results obtained in the study the shaking speed at 150 rpm yielded maximum keratinase production. But the production of keratinase start decreasing after $150 \mathrm{rpm}$ and found lowest production at $300 \mathrm{rpm}$. Generally, increased shaking speed provided high oxygen transfer rate supporting cell growth. But high shaking speed (200-300 rpm) may give good bacterial growth but it lowers rate of keratinase production possibly because of too high dissolved oxygen and too much shear stress which may have repressed keratinase synthesis and excretion. While at low shaking speed $(100 \mathrm{rpm})$, low keratinase production was observed, this could be due to at low shaking speed bacterial cells and substrate were not well mixed with heterogeneous distribution and lower oxygen dissolved at this speed results in low keratinase production. Similar results were reported in some of the previous studies such that (Pissuwan and Suntornsuk, 2001) reported shaking speed of $150 \mathrm{rpm}$ yielded maximum keratinase production by Bacillus sp. FK 28. (Hossain et al., 2007) reported $120 \mathrm{rpm}$ of agitation speed for maximum keratinase production from B. licheniformis MZK-3. But on the other hand present study was found contradictory to the results of previous studies for example Cai et al., (2011), Jeong et al., (2010), Park and Son (2007), Refai et al., (2005) reported $200 \mathrm{rpm}$ of agitation speed for maximum keratinase production by $B$. pumilus FH-9, B. megaterium F7-1, Stenotrophomonas maltophila R-13 respectively.

\section{Effect of substrate concentration}

In the present study the effect of substrate concentration on the production of keratinase by Bacillus subtilis was studied for a substrate concentration range of $1 \%$ to $3 \%$ which is shown in (Fig. 7). According to the results the highest keratinase production was obtained at $1 \%$ feather powder concentration. Keratinase produced at a level of $0.5 \%$ feather powder was less than that produced at $1 \%$ feather powder. This may be because the amount of substrate supplied for growth and enzyme 
production was insufficient, while substrate concentration above $1 \%$ i.e. from $1.5 \%-3 \%$ showed a decreasing trend in keratinase production. This decreasing trend in keratinase production above $1 \%$ feather powder concentration is due to substrate repression on keratinase production. High feather powder concentration may also have increased the medium viscosity which possibly results in oxygen limitation for bacterial growth. The results in the present study were found in accordance with the previous studies in the keratinase production. Cheng et al., (1995) reported that 1\% feather powder gave the highest keratinase activity for B. licheniformis PWD-1. Brandelli and Riffle (2005) also indicated that the production of keratinase by Chryseobacterium sp. Kr6 was repressed by higher percent of keratin substrate in the production medium.

\section{Effect of additional carbon source}

The effect of different carbon sources such as Lactose, maltose, fructose, glucose, sucrose, dextrose and mannitol on keratinolytic enzyme production from Bacillus subtilis is shown in (Fig. 8). Bacillus subtilis produced appreciable level of keratinolytic enzyme when cultivated in a medium containing feather as the sole carbon source. Additionally, additional carbon sources adversely affected the production of keratinase enzyme and lower enzyme production was achieved as compared to control in which only feather was used as carbon source. A decrease in the keratinase production due to the addition of conventional carbon sources is reported in the present study were in agreement with the earlier research, for example, Anbu et al., (2007), Ignatova et al., (1999), Yamamura et al., (2002) described that the decrease in keratinase production by adding conventional carbon sources may be due to the catabolic repression of keratinase. Kainoor and Naik (2010) illustrated that keratinase production from Bacillus sp. JB 99 was most inhibited in the presence of dextrose, followed by citric acid and glucose. Ramnani and Gupta (2004) in case of Bacillus sp. MIR-99 also found that addition of glucose, glycerol and sucrose to the production medium suppressed the enzyme secretion.

\section{Effect of additional nitrogen source}

The effect of different nitrogen sources such as beef extract, peptone, yeast extract urea, ammonium nitrate, ammonium sulfate and ammonium chloride on keratinolytic enzyme production from Bacillus subtilis was studied as shown in (Fig. 9). Bacillus subtilis produced appreciable level of keratinolytic enzyme when cultivated in a medium containing feather as the sole nitrogen source. Additionally, extra nitrogen sources such as beef extract, peptone, and yeast extract had a positive influence on enzyme production, resulting in considerable increases in enzyme production over the control. On the other hand, when other nitrogen sources such as urea, ammonium nitrate, ammonium sulfate and ammonium chloride were used as extra nitrogen sources in production medium, reduced enzyme production considerably. Maximum enzyme $(13.71 \mathrm{U} / \mathrm{ml})$ production was obtained in presence of Beaf extract as additional nitrogen source and minimum $(2.62 \mathrm{U} / \mathrm{ml})$ in presence of urea. These results were in accordance with those in some previous investigations. For instance, (Park and Son 2009) found that beef extract, casein, gelatin, skim milk, tryptone, and yeast extract had a positive influence on enzyme production by Bacillus megaterium F7-1. (Malviya et al., 1992) also found similar results for Chrysosporium queenslandicum. However, results of this study were also found in contrast with some studies of the previous literature for example (Refai et al., 
2005) showed that extra $\mathrm{NH} 4 \mathrm{Cl}$ as nitrogen source have a favorable effect on keratinase production by $B$. pumilus FH9. (Nilegaonkar et al., 2007) reported that increased level of keratinase production by $B$. cereus MCM B326 was observed to be up due to the addition of ammonium chloride and sodium nitrite compared with other inorganic nitrogen sources.

Keratinases are the special class of proteolytic enzymes which have gained importance in various industries such as in pharmaceutical, cosmetic, leather and feed processing industry, as well as in keratin waste treatment. Various production parameters were optimized to produce keratinase by Bacillus subtilis $\mathrm{S} 1$. This strain displayed good capability of keratinase production after $72 \mathrm{~h}$ of incubation at $40^{\circ} \mathrm{C}$ and $\mathrm{pH} 7.0$, with agitation level of $150 \mathrm{rpm}$ in a $1 \%$ feather concentration. The best additional nitrogen source was Beaf extract and all the additional carbon sources showed a negative effect on keratinase production. These results indicate that this bacterial strain shows a high potential for keratinase production in submerged-state fermentation, and use of feather waste as the substrate can be implemented for keratinous solid waste management.

\section{Acknowledgment}

The author wish to thank Honorable ViceChancellor, SHUATS and HOD, Department of Microbiology and Fermentation Technology, Sam Higginbottom University of Agriculture, Technology and Sciences for providing laboratory support.

\section{References}

Alessandro R., Adriano B. 2006. Keratinolytic bacteria isolated from feather waste. Brazilian J. Microbiology. 37: 395.
Allpress J.D., Mountain G., Gowland P.C. 2002. Production, purification, and characterization of an extracellular keratinase from Lysobacter NCIMB 9497. Letters in Applied Microbiology. 34: 337-342.

Anbu P., Gopinath S.C.B., Hilda A., Lakshmipriya T., Annadurai G. 2007. Optimization of extracellular keratinase production by poultry farm isolate Scopulariopsis brevicaulis. Bioresour. Technol. 98: 1298-1303.

Bradbury J.H. 1973. The structure and chemistry of keratin fibers. Advances in Protein Chemistry. 27: 111-211.

Brandelli A. and Riffle A. 2005. Production of an extracellular keratinase from Chryseobacterium sp. growing on raw feathers. Elect J Biotechnol. 8: 35-42.

Bressolier P., Letourneau F., Urdaci M., and Verneuil B. 1999. Purification and characterization of a keratinolytic serine proteinase from Streptomyces albidoflavus. Applied and Environmental Microbiology. 65: 2570-2576.

El-Refai H.A., AbdelNaby M.A., Gaballa A., El-Araby M.H., Abdel Fattah A.F. 2005. Improvement of the newly isolated Bacillus pumilus FH9 keratinolytic activity. Process Biochem. 40(7): 2325-2332.

Gessesse A., Hatti-Kaul R., Gashe B.A., Mattiasson B. 2003. Novel alkaline proteases from alkaliphilic bacteria grown on chicken feather. Enzyme Microb Technol. 32: 519-524

Hossain M.S., Azad A. K., Abu Sayem S.M., Mostafa G., Hoq M.M. 2007. Production and partial characterization of feather-degrading keratinolytic serine protease from Bacillus licheniformis MZK-3. J. Biol. Sci. 7 (4): 599-606.

Ignatova Z., Gousterova A., Spassov G., Nedkov P. 1999. Isolation and partial 
characterization of extracellular keratinase from a wool degrading thermophilic actinomycete strain Thermoactinomyces candidus. Can. J. Microbiol. 45: 217-222.

Jahan Z, Khan SN, and Mozammel Hoq M, Screening of keratinolytic bacteria from Poultry Wastes. Bangladesh J Sci Ind Res, 45(3): 261-266, (2010).

Jeong J.H., Lee O.M., Jeon Y.D., Kim J.D., Lee N.R., Lee C.Y. and Son H.J. 2010. Production of keratinolytic enzyme by a newly isolated feather degrading Stenotrophomonas maltophilia that produces plant growth-promoting activity. Process Biochemistry.45: 1738-1745.

Kainoor S.P. and Naik G.R. 2010. Production and characterization of feather degrading keratinase from Bacillus sp. JB 99. Indian J Biotechnol. 9: 384390.

Kaul S. and Sumbali G. 1997. Keratinolysis by poultry farm soil fungi. Mycopathologia. 139, 137-140.

Kim J.M., Lim W.J., and Suh H.J. 2001. Feather-degrading Bacillus species from poultry waste. Process Biochemistry. 37: 287-291.

Lateef J.K., Oloke E.B., Gueguim Kana B.O., Sobowale Ajao S.O., Bello B.Y. 2010. Keratinolytic activities of a new feather-degrading isolate of Bacillus cereus LAU 08 isolated from Nigerian soil. International Biodeterioration \& Degradation. 64: 162-165.

Lin H.H. and Yin L.J. 2010. Feather meal and rice husk enhanced keratinase production by Bacillus licheniformis YJ4 and characterization of produced keratinases. J. Mar. Sci. Technol. 18(3): 458-465.

Lin X., Inglis G.D., Yanke L.J., and Cheng K.J. 1999. Selection and characterization of feather degrading bacteria from canola meal compost.
Journal of Industrial Microbiology and Biotechnology. 23: 149-153.

Malviya, H.K., Rajak R.C., Hasija S.K. 1992. Synthesis and regulation of extracellular keratinase in three fungi isolated from the grounds of a gelatin factory, Jabalpur, India. Mycophathologia. 120: 1-4.

Nilegaonkar S.S., Zambare V.P., Kanekar P.P., Dhakephalkar P.K., and Sarnail S.S. 2007. Production and partial characterization of dehairing protease from Bacillus cereus MCM B-326. Bioresour. Technol.98: 1238-1245.

Onifade A.A., Al-Sane N.A., Al-Musallam A.A., and Al-Zarban S. 1998. Potentials for biotechnological applications of keratindegrading microorganisms and their enzymes for nutritional improvement of feathers and other keratins as livestock feed resources. Bioresource Technology. 66: 1-11.

Papadopoulos M.C., El Boushy A.R., Roodbeen A.E., and Ketelaars E.H. 1986. Effects of processing time and moisture content on amino acid composition and nitrogen characteristics of feather meal. Animal Feed Science and Technology. 14: 279-290.

Park G.T and Son H.J. 2009. Keratinolytic activity of Bacillus megaterium F7-1, a feather degrading mesophilic bacterium. Microbiol Res. 164: 478485.

Pissuwan D. and Suntornsuk W. 2001. Production of keratinase by Bacillus sp. FK 28 isolated in Thailand. Kasetsart Journal (Natural Science). 35: 171-178.

Ramnani P. and Gupta R. 2004. Optimization of medium composition for keratinase production on feather by Bacillus licheniformis RG1 using statistical methods involving response surface 
methodology. Biotechnol Appl Biochem. 40: 491-496.

Riffel A.\& Brandelli A. 2006. Keratinolytic bacteria isolated from feather waste. Brazilian Journal of Microbiology, 37: 395-399.

Sahoo D.K., Das A., Thatoi H., Mondal K.C., Das P.K., Mohapatra. 2012. Keratinase Production and Biodegradation of Whole Chicken Feather Keratin by a Newly Isolated Bacterium Under Submerged Fermentation. Appl Biochem Biotechnol. DOI 10.1007/s12010-0119527-1.

Saibabu V., Niyongabo F., Niyonzima and Sunil S.M. 2013. Isolation, Partial purification and Characterization of Keratinase from Bacillus megaterium. International Research Journal of Biological Sciences, 2(2): 13-20.

Sivakumar T., Shankar T., Thangapandian V., Ramasubramanian V. 2013. Optimization of Cultural Condition for Keratinase Production Using Bacillus cereus TS1. Insight Microbiology, 3(1): 1-8.

Suh H.J., Kim J.M. and Lim W.J. 2001. Feather-degrading Bacillus species from poultry waste, Process Biochem. 37: 287-291.

Suntornsuk W. and Suntornsuk L. 2003. Feather degradation by Bacillus species FK 46 in submerged cultivation. Bioresource Technology. 86: 239-243.

Williams C.M., Richester C.S., Mackenzi J.M., and Shih J.C.H. 1990. Isolation, identification and characterization of a feather degrading bacterium. Appl. Environ. Microbiol. 56: 1509-1515.

Yamamura S., Morita Y., Hasan Q., Rao S.R., Murakami Y., Yokoyama K., Tamiya E. 2002. Characterization of a new keratin-degrading bacterium isolated from deer fur. J. Biosci. Bioeng.93: 595-600.

\section{How to cite this article:}

Sandeep Singh, Harison Masih, G. Ebenezer Jeyakumar, Rubina Lawrence and Ramteke, P.W. 2017. Optimization of Fermentative Production of Keratinase by Bacillus subtilis Strain S1 in Submerged State Fermentation Using Feather Waste. Int.J.Curr.Microbiol.App.Sci. 6(12): 1499-1510. doi: https://doi.org/10.20546/ijcmas.2017.612.167 